particular form, trainees' performance should be assessed in the following areas: (a) ability in history taking, formulation and oral and written case presentation; (b) therapeutic skill and judgement, including ability in specific treatment techniques; (c) relationships with patients and their relatives and with colleagues (medical and non-medical); (d) theoretical knowledge of psychiatry; (e) knowledge of, and skill in, general medicine; (f) initiative, reliability, self-reliance and administrative ability; (g) command of English language (where appropriate).

It is important for the assessment to describe the trainee's particular strengths and weaknesses and to state the trainer's views about any action needed and career prospects. A rating of ability in each area on a simple 3 or 5 point scale provides a useful profile, but there should also be adequate space for narrative comment.

Formal assessments should always be discussed by the consultant and the tutor with the trainee but should otherwise remain confidential. The trainee should be asked to add his own written comments, including his views as to the quality of content and training on that placement. The report should remain with the psychiatric tutor and remain confidential between consultant, tutor and trainee concerned.

\title{
College Notices
}

\section{Stop Press}

It was announced at the meeting of Council on 19 March that the new President of the College will be Kenneth Rawnsley, Professor of Psychiatry at the Welsh National School of Medicine.

\section{A Helping Hand}

A year ago the Research Committee expressed its willingness to help those who were experiencing difficulties in undertaking research projects and who were unable to get advice from other sources (Bulletin, May 1980). A number of individuals have already sought help and I hope, received it. We would again like to draw attention to our readiness to be of assistance.

Sheila A. ManN Secretary, Research Committee

\section{Tenth Psychiatric Tutors' Conference}

The next Psychiatric Tutors' Conference is to be held at the University of Kent at Canterbury from 24 to 26 September 1981. Tutors are invited to send suggestions for topics for discussion to Dr I. G. Bronks at the College. Enquiries to Jane Boyce, also at the College.

\section{Psychotherapy Section Scientific Meeting}

Dr Fay Fransella, Reader in Clinical Psychology at the Royal Free Hospital, will be talking about Perronal Constructs in Paychotherapy at the College at $8.00 \mathrm{pm}$ on 20 May 1981. All members of the College are welcome to attend.

\section{Officers of the Divisions}

\author{
Chiltern and Thames Valley Division \\ Chairman: Dr J. Steinert \\ Secretary: Dr S\& Montgomery \\ Representative Fellow on Council: Dr E. W. Shepherd \\ Representative Member on Council: Dr Diana Dickens \\ Executive Committee: Drs B. Alapin, B. Chester, T. Crow, \\ R. Cundall, H. A. Dickinson, W. B. Knapman, Professor \\ R. G. Priest, Dr V. Wilkinson. \\ Co-opted: Dr A. R. M. Freeman, J. B. McWhinnie \\ Collegiate Trainees Representatives: Drs. M. Bowker and D. \\ Costain \\ East Anglian Division \\ Chairman: Sir Martin Roth
}

Secretary: Dr Digby Hall

Representative Fellow on Council: Dr A. G. Mezey

Representative Member on Council: Dr Digby Hall

Executive Committee: Drs. S. Cohen, G. Goldberg, D. M. Lynch, F. McEvett, A. Mitchell, B. F. Whitehead

Collegiate Trainees Representatives: Drs H. Ghadiali and G. Holt

\section{Irish Division}

Chairman: Professor T. Lynch

Secretary: Dr D. Shanley

Represenatative Fellows on Council: $\mathrm{Dr}$ A. S. Clenaghan and Professor T. Lynch (alternate) 